\title{
Architectural Interventions Conducted in Yıldız Palace During the Second Constitutional Period (1909-1914)*
}

\author{
II. Meşrutiyet Dönemi'nde Yıldız Sarayı'nda Gerçekleştirilen Mimari Müdahaleler \\ (1909-1914)
}

\section{Müjde Dila Gümüş̧*}

\begin{abstract}
This study focuses on the architectural interventions that took place in Yıldız Palace and which were conducted by the chief imperial architect Vedad Bey during the Second Constitutional Period. After the request of Mehmed Reşad V to spend the summer months at Yıldız Palace rather than at his primary residence Dolmabahçe Palace, Yıldız Palace became a priority for the sermimar, the person responsible for the maintenance and repair of the structures used by the imperial family (mainly Dolmabahçe, Yıldız, Topkapı, and Beylerbeyi Palaces and the imperial pavilions in Istanbul). Consequently, extensive renovations were conducted in the palace by Vedad Bey. The aim of this research is to to reveal the constructions and renovations carried out at the palace under the supervision of Vedad Bey by examining documents from the Presidency of The Republic of Turkey Directorate of State Archives such as Vedad Bey's survey notebooks, architectural drawings, and petitions. This archival research reveals that the most significant architectural intervention in the palace during the Constitutional period was the demolition of the palace cuisine. Additionally, this research reveals a previously unknown design of Vedad Bey, namely the soldier sentry boxes of Yıldız Palace, which are here introduced by architectural drawings, a survey notebook, and a photograph. Additionally, repairs carried out in almost every apartment of the palace have been documented.
\end{abstract}

\section{Keywords}

Yıldız Palace, Vedad Tek, Second Constitutional Period, Late Ottoman Architecturet

\section{Öz}

Bu çalışma, II. Meşrutiyet döneminde Yıldız Sarayı'nda 'sermimar-ı hazret-i şehriyari' Vedad (Tek) Bey tarafından gerçekleştirilen mimari müdahalelere odaklanmaktadır. Saltanatı süresince Dolmbahçe Sarayı'nda ikamet etmiş Sultan V. Mehmed Reşad'ın, yaz aylarını Yıldız Sarayı'nda geçirmeyi talep etmesiyle, sarayda kapsamlı onarımlar gerçekleştirilmeye başlanmıştır. Bu durum, Yıldız’ı, hanedan tarafından kullanılan yapıların (başlıca: Dolmabahçe, Yıldız, Topkapı, Beylerbeyi Sarayları ile İstanbul'da bulunan kasırların) bakım ve onarımından sorumlu olan sermimar için öncelikli bir konuma getirmiştir. Bu araştırma kapsamında, Başbakanlık Osmanlı Arşivi'nde bulunan ve Vedad Bey tarafından hazırlanmış keşif defterleri, çizimler ve kaleme alınmış dilekçelerden faydalanarak II. Meşrutiyet Dönemi'nde sarayda Vedad Bey'in yönetiminde gerçekleştirilen inşa ve onarım faaliyetlerinin ortaya konulması amaçlanmıştır. II. Meşrutiyet yıllarında sarayda

* Bu makale, İstanbul Üniversitesi, Sosyal Bilimler Enstitüsü Sanat Tarihi Anabilim Dalı Doktora Programı́nda Prof. Dr. Agah Tarkan Okçuoğlu danışmanlığında Müjde Dila Gümüş tarafindan hazırlanan “ikinci Meşrutiyet’te Saray Iç̧in Çalışmak: Vedad (Tek) Bey'in Sermimarlık Dönemi" başlıklı doktora tezinden geliştirilmiştir.

** Correspondence to: Müjde Dila Gümüş (Arş. Gör. Dr.), İstanbul Üniversitesi, Sanat Tarihi Bölümü, İstanbul, Türkiye. E-mail: dilagumus@hotmail.com ORCID: 0000-0003-0978-4924

To cite this article: Gumus, Mujde Dila. "Architectural Interventions Conducted in Yıldız Palace During the Second Constitutional Period (1909-1914)." Art-Sanat, 15(2021): 93-108. https://doi.org/10.26650/artsanat.2021.15.0004 
gerçekleştirilen en büyük kapsamlı müdahalenin, saray mutfaklarının yıkılması olduğu tespit edilmiştir. Vedad Bey'in saray için projelendirdiği asker kulübelerinin mimari çizimlerine, keşif defterlerine ve fotoğraflarına ulaşılarak, Vedad Bey'in bilinmeyen bir tasarımı tanıtılmıştır. Bununla beraber, sarayın hemen her dairesinde gerçekleştirilen onarımlar belgelenmiştir.

Anahtar Kelimeler

Vedad Tek, II. Meşrutiyet Dönemi, Yıldız Sarayı, Geç Dönem Osmanlı Mimarlığı

\section{$\underline{\text { Genisletilmis } \ddot{O}_{z} \text { et }}$}

III. Selim döneminde yapılaşmanın başladığı ve II. Abdülhamid dönemindeki yoğun inşa faaliyetleri sonucunda günümüzdeki görünümüne ulaşan Yıldız Saray1, pek çok araştırmaya konu olmuştur. Ancak, sarayda II. Meşrutiyet yıllarında gerçekleşen mimari müdahaleler, bilinmezliğini korumaktadır. Bu çalışma, II. Meşrutiyet döneminde Yıldı Sarayı'nda 'sermimar-ı hazret-i şehriyari' Vedad Bey yönetiminde gerçekleştirilen mimari faaliyetlere odaklanmaktadır. II. Abdülhamid'in 1909 yılında tahttan indirilmesinin ardından, onun, hanedan üyelerinin ve saray çalışanlarının yaşamış olduğu Yıldız Sarayı da hanedanın ikametgâhı olma niteliğini yitirmiştir. II. Abdülhamid'in otuz üç yıllık iktidarı ile özdeşleşen saray, II. Meşrutiyet yönetimi için, dönemin saray başkâtibi Halid Ziya (Uşaklıgil) Bey'in ifadesiyle "acayip" ve zorlu bir miras hâline gelmiştir. Önceki dönemin izleri mümkün olduğunca silinmeye çalışılırken, tahta çıkan V. Mehmed Reşad'ın ikameti için Dolmabahçe Sarayı uygun görülmüştür. Dolmabahçe Sarayı'nın sermimar Vedad Bey yönetiminde kapsamlı bir onarımdan geçirilmesi ile birlikle V. Mehmed Reşad ve maiyeti buraya yerleşmiştir. Yıldız Sarayı ise, Bulgar ve Sırp kralları gibi üst düzey ziyaretçilerin ağırlanmasında kullanılmaya başlanmıştır. V. Mehmed Reşad'ın tahta çıktıktan bir sene sonra, yaz aylarını Yıldız Sarayı'nda geçirmeyi talep etmesinin ardından, sarayda çeşitli onarımların gerçekleşmesi gündeme gelmiştir. Bu durum, Yıldız Sarayı'nı, hanedan tarafından kullanılan yapıların (Dolmabahçe Sarayı, Yıldız Sarayı, Topkapı Sarayı, Beylerbeyi Sarayı ile İstanbul'da bulunan kasırların) bakım ve onarımından sorumlu olan sermimar Vedad Bey için öncelikli bir çalışma alanı konumuna getirmiştir.

Vedad Bey, görevi süresince, yapılacak her inşa ve onarım faaliyeti için düzenli olarak ön keşif (keşf-i evvel) defterleri tutmuştur. Cumhurbaşkanlığ Devlet Arşivleri, Hazine-i Hassa Ebniye Anbarları fonunun 1909-1914 arasına tarihlenen dosyalarının taranması sonucunda, Vedad Bey'in keşif defterlerinden 475 tanesi tarafımca tespit edilmiş ve incelenmiştir. Keşif defterlerinin yarısına yakını, Sultan V. Mehmed Reşad'ın ikametgâhı olan Dolmabahçe Sarayı ve ek yapılarını konu alırken; 84 keşif defteri ise Yıldız Sarayı'na ilişkin onarımlarını içermektedir. Bu tespit, V. Mehmet Reşad'ın baş mimarının, Dolmabahçe Sarayı'ndan sonra en yoğun çalıştığı yapının Yıldız Sarayı olduğunu göstermektedir. 
Saray için 1910 y1lı sonu ve 1911'de hazırlanan keşif defterleri, Şale Köşkü, Merasim Köşkü, Küçük Mabeyn, Müzehâne, Yeni Köşk, Büyük Mabeyn, Cihannümma ve Çit Kasrı gibi pek çok yapıda çatı onarımı gibi bazı temel onarımları kapsamaktadır. Öncelikli olarak ele alınan yapı, Büyük Mabeyn’dir. Hem Vedad Bey’in keşif defterlerinde, hem de Halid Ziya Bey’in anılarında onarıma muhtaç durumda olduğu belirtilen Büyük Mabeyn, sarayın diğer yapılardan farklı olarak kapsamlı bir onarımdan geçirilmiştir. Ardından, Telgrafhane ile Büyük Mabeyn arasındaki alanda yer alan yapı grubunu (Kilere bitişik daireler, harem ağaları dairesi, telgrafhane ve civarındaki daireler) konu alan bir onarım planı hazırlanmıştır. Arka arkaya hazırlanmış olan bu keşifler, duvarların onarımı ve boyanması, kapıların boyanması, kırık camların yenilenmesi, panjur ve çerçevelerin onarımı, bazı daire ve avluların çiçekli çini ile kaplanması gibi birbirlerine benzer içeriklere sahiptir. Hepsinde ortak olarak vurgulanan ise, müdahalelerin mümkün olduğunca aslına uygun yapılmasıdır.

Yıldız Sarayı'nın II. Meşrutiyet döneminde onarımdan geçen bir başka yapısı, Daire-i Hümâyun'dur. Padişahın kullanımına özel olan bu yapı için hazırlanan keşif defterlerinin, diğer daireler için hazırlananlara göre daha detaylı talimatlar içerdiği gözlemlenmiştir. Aynı dönemde, saray bahçesinde bulunan köprülerden biri değiştirilmiş ve yine saray bahçesine yeni bir tuvalet yaptırılmıştır. Ada Köşkü'nün giriş cephesi tamamen sökülerek yenilenmiş ve köşke bir kahve ocağ 1 eklenmiştir.

II. Meşrutiyet döneminde Yıldız Sarayı'nda herhangi bir ek yapı inşa edildiğine dair bir veriye ulaşılmamıştır. Bu kapsamda değinilebilecek nadir bir örnek, sarayın çeşitli mahallerine yerleştirilmek üzere Vedad Bey tarafından tasarlanmış olan asker nöbet kulübeleridir. Köşeleri pahlı kare planlı, üzerine bir alem yerleştirilmiş dilimli külah ile örtülü ahşap kulübeler, Milli Mimari üslubunu yansıtan küçük ölçekli tasarım örnekleri olarak dikkat çekmektedir. Vedad Bey’in bu bilinmeyen tasarımının çizimleri, üretim talimatları ve fotoğrafları, bu çalışma kapsamında tespit edilmiş ve incelenmiştir.

Yıldız Sarayı'nda Vedad Bey yönetiminde gerçekleştirilen en kapsamlı müdahale, saray mutfağının yıkılmasıdır. Bu yıkım, Yıldız Sarayı'na ilişkin yeni bir tespit olması bakımından önem taşımaktadır. Mutfak yıkımını konu alan arşiv belgelerinde, saray mutfağına artık ihtiyaç olmadığı, bu sebeple yıkılacağı ve arazisinin bahçeye dönüştürüleceği ifade edilmektedir. 1909 tarihinde L'Illustration gazetesinde yayınlanan Yıldız Sarayı vaziyet planı ile Sedad Hakkı Eldem'in 1960'ların sonunda hazırladığı vaziyet planının karşılaştırılmasından yola çıkarak, yıkılan mutfak binasının Büyük Mabeyn ile Telgrafhane arasında, Ağalar Dairesi'nin hemen arkasında konumlanmış olabileceği anlaşılmaktadır. Vedad Bey'in saraya yaptırılan yeni mutfağı konu alan çeşitli keşif çalışmaları da mevcuttur. Bunlar arasında en dikkat çekici olanı, "Yı1dız Saray-1 Hümâyunu'nda demirhanede tesis edilecek olan mutfakta bulaşık yıkamak 
için inşa olacak mermer tekneler" başlıklı olup hem yıkılan mutfakların yerine demirhanede yeni bir mutfak oluşturulmasının planlandığını ortaya koymakta; hem de yeni mutfakta kullanılacak olan mermer bulaşı teknelerinin tasarım ve üretim talimatlarını içermektedir. Saray mutfaklarının yıkılması ve demirhanenin mutfak olarak işlevlendirilmesini konu alan keşif defterleri ve yazışmaların tespit edilerek incelenmesi sonucunda, Yıldız Sarayı'na ilişkin büyük ölçekli ve önceki araştırmalara konu olmamış bir mimari müdahalenin detayları ortaya koyulmuştur. 


\section{Introduction}

The dethronement of Abdulhamid II (r. 1876-1909) in 1909 brought about many significant changes in the rule of the Ottoman State. Within the Empire's adminstration system the power of the court decreased while the parliament, consisting of members of the Committee of Union and Progress, became the foremost political authority. ${ }^{1}$ Mehmed Reşad V (r. 1909-1918), who came to the throne after Abdülhamid II, continued a reign that did not have much influence on administrative decisions. After the dethronement in 1909, many significant steps were taken to distance the new reign's rule from Abdülhamid II's. One of those steps was that the new sultan, Mehmed Reşad V, would reside at Dolmabahçe Palace instead of at Yıldız Palace.

Located on the hills of the Beşiktaş district, and consisting of various buildings mostly constructed during his reign, Yıldız Palace is most well known as the primary residence of Abdulhamid II. While it is a well-known and thoroughly researched architectural complex in the literature, ${ }^{2}$ its status during the Second Constitutional Period has mostly been neglected in the context of architectural history. In this paper, some of the more noteworthy architectural interventions in Y1ld1z Palace conducted by Mehmed Reşad V's chief architect (sermimar-l hazret-i şehriyari) Vedad Bey ${ }^{3}$

1 For detailed information on the reign of Abdülhamid II, see Selim Deringil, The Well-protected Domains: Ideology and the Legitimation of Power in the Ottoman Empire, 1876-1909 (New York: I.B. Tauris Press, 1998). For Second Constitutional Period, see Feroz Ahmad, The Young Turks; the Committee of Union and Progress in Turkish Politics, 1908-1914 (Oxford: Clarendon Press, 1969).

2 Bülent Bilgin, "Türk Saray Mimarisinin Gelişmesi Çerçevesinde Yıldız Sarayı" (PhD. dissertation, Istanbul University, 1993); Afife Batur, "Yıldız Saray1”, Dünden Bugüne İstanbul Ansiklopedisi, v.7 (İstanbul: Türkiye Ekonomik ve Toplumsal Tarih Vakfı, 1993), 520-556; Pars Tuğlacı, Osmanlı Mimarlı̆̆ında Batılllaşma Dönemi ve Balyan Ailesi, (İstanbul: İnkılap ve Aka Kitabevleri, 1981); Deniz Türker, "Ottoman Victoriana: Nineteenth-Century Sultans and the Making of a Palace, 1795-1909" (PhD. dissertation, Harvard University, 2016).

3 Vedad Bey, who was born in 1873, was a member of a family that had strong ties with the Ottoman Court. His father Sirrı Pasha from Crete, was a bureaucrat who served as the governor of Trabzon, Diyarbakır, some Rumeli states and Bagdad. İsmail Pasha, the Doctor, who was his grandfather on his mother side, was the court doctor for Mahmud II. Vedad's mother, Leyla (Saz) Hanım, who was a composer and a poet, spent seven years at the court under the reign of Sultan Abdülmecid, when she had, in Nihad Tek's words, "one foot at the Sultan's court." Vedad started his education at Mekteb-i Sultâni and continued it in Paris. Then, he studied architecture at Beaux-Arts for four years and in 1898, he returned to Istanbul. First he opened his own architecture Office, and the following year he started teaching at the Academy of Fine Arts (Sanayi-i Nefise Mektebi) and then he was appointed as City Council Technical Committee architect (ssehremaneti heyet-i fenniye mimart). In the following years, he served as the architect of Izmit Clock Tower (1901-02), Kastamonu Government Office (1902), Ministry of Post and Telagraph (Posta ve Telgraf Nezareti) (19041909), Hobyar Mosque, Ministy of Land Registry (Defter-i Hakani Nezareti) (1907-1908). In particular, the Ministry of Post and Telagraph building was a milestone in Vedad Bey's career. This building is considered to be one of the most significant samples of the Turkish National Style movement. When Mehmed Reşad V ascended to the throne, Vedad Bey was an architect who had strong family ties and who was also at the peak of his career. Süha Özkan, “Mimar Vedat Tek (1873-1942)”, Mimarlk 11-12 (1973), 45-51. Leyla Saz, 19. Yüzyllda Saray Haremi (İstanbul: Cumhuriyet Kitapları, 2000), 11-12. For detailed information see M. Vedad Tek: Kimliğinin İzinde Bir Mimar, ed. Afife Batur (İstanbul: Yapı Kredi Yayınları, 2003). .d)hat Tek, Selma Sarı.viş, uz, şortaya konmuştur. nda, Yıldız Sarayı'esi sonucunda, azırlananlara göre daha detaylı talimatlar .d)hat Tek, Selma Sarı.viş, uz, şortaya konmuştur. nda, Yıldız Sarayı'esi sonucunda, azırlananlara göre daha detaylı talimatlar 
between 1910-1914 are revealed, and some interest in this previously unexamined era in the history of the Palace history is revived. This study demonstrates that when the palace became Mehmed Reşad V's summer residence between 1910-1914, Vedad brought about various architectural interventions that have been overlooked and which deserve further study. Within the scope of this article, renovations carried out at Yildiz Palace under the supervision of Vedad Bey are revealed based on documents from the The Presidency of The Republic of Turkey Directorate of State Archives - his survey notebooks, architectural drawings, and petitions.-

\section{The Function of Yıldız Palace in The Second Constitutional Period}

The construction of the palace within the Yildiz hills began in the reign of Selim III (r. 1789-1808) with a kasır and a fountain. Abdülaziz (r. 1861-1876) expanded the complex by building structures such as Mabeyn Kiosk and Çit Pavilion. The palace gained its present appearance during the reign of Abdulhamid II with the construction of Small Mabeyn (Kü̧̈ük Mabeyn), harem apartments, Şale Mansion, Yıldız Mosque, a theater, a carpentry, a tile factory, prince mansions, and various other buildings. The Sultan used this place as his primary residence for security reasons, and the palace has become a symbol of his 33-year reign. ${ }^{4}$

To illustrate the perception that most people had of Yildiz Palace during the period of its disuse before Mehmed Reşad V took it as his summer residence, we can take a close look at the words of Halid Ziya (Uşaklıgil) Bey. Halid Ziya, who had close ties with the Committee of Union and Progress, was assigned as Chief Secretary (ser kâtib-i hazret-i şehriyari), to Mehmed Reşad V in 1909. In Halid Ziya's memoirs, there is a detailed chapter on Yildız Palace. ${ }^{5}$ The concepts he used in this chapter to define the palace reveal intriguing clues about how it was perceived during the Second Constitutional years at least through the eyes of a high-ranked state official and a writer who was related to the Committee of Union and Progress. The first sentence of the chapter itself reflects the enigmatic perception of the palace:

"This was a mystery, a mystery that tickles the minds both inside and outside the country during the reign of Sultan Abdülhamid with various suppositions and rumors for thirty-three years, and with a curiosity that increased day by day; then, I think it is still a mystery that brings about doubt about how this strange heritage will be solved ..."

Following the dethronement of Sultan Abdülhamid II, Yıldız Palace, the place of his primary residence and which had mostly been built during his reign and had been identified with him, was evacuated. Additionally, it was not even certain how the palace would function for a while. ${ }^{7}$ The first official function of Y1ld1z Palace after 1909 was

4 François Georgeon, Sultan Abdülhamid, trans. Ali Berktay, (İstanbul: İletişim Yayınları, 2015), 174-175.

5 Halid Ziya Uşaklıgil, Saray ve Ötesi (İstanbul: Özgür Yayınları, 2003), 189-206.

6 Uşaklıgil, Saray ve Ötesi, 189.

7 Uşaklıgil, Saray ve Ötesi, 357-358. 
receiving high-ranking guests. When the Bulgarian King and Queen visited Istanbul in 1910, Y1ldiz Palace was allocated to them for their stay. ${ }^{8}$ The Ceremonial Apartment (Merasim Dairesi), Şale Kiosk and the Small Mabeyn (Küçük Mabeyn) were prepared for the guests without much effort. Soon after this visit, the Serbian King also stayed at Yildı Palace. ${ }^{9}$ But shortly after, the palace was given a more critical function than temporarily hosting high-ranking guests. The issue of how to use Y1ldiz Palace was solved when Sultan Mehmed Reşad V decided to spend his summers there due to the climate being more suitable than that at Dolmabahçe Palace during the summer months. ${ }^{10}$ The eagerness of the Sultan to move from Dolmabahçe Palace to Y1ldız Palace is revealed both in the imperial decrees which state that repair work at Y1ldiz Palace should be given priority, ${ }^{11}$ and in the diaries of Grand Vizier Mahmud Şevket Pasha in the following years. The Grand Vizier Mahmud Şevket Pasha frequently wrote about the Sultan's desire to move to Y1ld1z Palace in April and May 1913:

\footnotetext{
"He wanted to move to Yildiz at the beginning of May.";

"In his [sultan's] presence, we talked about peace and the renovations at Y1ldı.";

"His Majesty talked about food, moving to Yıldız, and some other basic topics.";

"This time we only talked about the Sultan's moving to Y1ldı."12
}

As a result of the Sultan's insistence on moving, the Grand Vizier turned his gaze to the renovations of Y1ldiz Palace, as recorded in his diary observations: "I went to Y1ldiz Palace, I saw the parts of the palace where the repair was carried out. All exterior parts were painted. The painting work was fine. In the interior, whitewashing and other work and some small repair were done."13

\section{Architectural Interventions in Yıldız Palace between 1909-1914}

As the palace became the second residence of the Sultan in 1911, the repair work to be done there constituted a significant place on the agenda of the chief imperial architect, Vedad Bey, who was responsible for the maintenance and repair of the structures used by the dynasty. Vedad Bey kept separate notebooks on the preliminary estimates of every repair, renovation, and construction. The survey notebooks were designed

8 For a detailed research on the Bulgarian King and Queen's visit, see Cengiz Yolcu, "Bulgar Çarı 'Çarlar Kenti'nde", Osmanl İstanbulu III, ed. Feridun M. Emecen, Ali Akyıldız, Emrah Safa Gürkan (İstanbul: 29 Mayıs Üniversitesi Yayınları, 2015), 243-288.

9 Uşaklıgil, Saray ve Ötesi, 357-358. Lütfi Simavi, Son Osmanlı Sarayında Gördüklerim (İstanbul: Örgün Yayınları, 2004), 91.

10 Cumhurbaşkanlığı Devlet Arşivleri (BOA), Hazine-i Hassa Ebniye Anbarları (HH.EBA.) 688/4/2, 23 Şubat 1326 (8 Mart 1911).

11 Cumhurbaşkanlığı Devlet Arşivleri (BOA), Hazine-i Hassa Ebniye Anbarları (HH.EBA.) 732/39/6, 6 Mart 1329 (19 Mart 1913).

12 Mahmud Şevket Paşa'nın Sadaret Günlüğ̈̈, prepared by Murat Bardakçı (İstanbul: İş Bankası Kültür Yayınlar1, 2014), 202, 244, 261, 290.

13 Bardakçı, Mahmud Şevket Paşa 'nin Sadaret Günlüğü, 291. 
especially for Vedad Bey; on the cover of each of them were his name and his title. The fact that the notebooks had consecutive numbers makes it possible to determine the number of construction and repair works conducted by Vedad Bey within the scope of his position. Entries in his first notebook started on 7 February 1910 and ended in book number 705 on 28 April 1914, just before his resignation. ${ }^{14}$ Based on this data, it is possible to state with certainty that there were over 700 preliminary estimates prepared by Vedad Bey between 1909-1914. As a result of my research at the Presidency of the Republic of Turkey Government Archives, 475 survey notebooks prepared by Vedad Bey were found and analyzed. ${ }^{15}$ Almost half of the notebooks are about Dolmabahçe Palace, the primary residence of Mehmed Reşad V, and the fact that 84 of the notebooks are on Yildiz Palace indicates that it is the second building that the chief architect worked on intensively.

The first comprehensive renovation project prepared by Vedad Bey for Y1ldız Palace dates to $1910 .{ }^{16}$ The first renovation mainly focussed on the roof repairs of Şale Kiosk, Ceremony Kiosk (Merasim Köşkü), Small Mabeyn (Küçük Mabeyn), the Museum (Müzehâne), the New Kiosk (Yeni Köşk), Mabeyn Kiosk, Cihannüma Pavillion, Şale Kiosk and Çit Pavillion. Another comprehensive renovation was conducted at the Mabeyn Kiosk. Both Vedad Bey's notebooks of 1910 and the memoirs of Halid Ziya reflect that the building had been neglected and was not suitable for proper use, hence the need for extensive repairs to be carried out. The renovation of Mabeyn Kiosk was one of the most expensive projects prepared for Y1ldız Palace. ${ }^{17}$ In the notebook kept by Vedad Bey specifically for Mabeyn Kiosk, he stated that a toilet on the first floor and the steps connecting the ground floor to the basement would be demolished. $\mathrm{He}$ also stated that the partitions in the basement would be removed. Other headings in the notebook are as follows: the repairs in the roof, terrace, windows, shutters, doors, flooring, removal of window walls, and painting. After the Mabeyn Kiosk, a series of repairs concentrating on the building group located between the telegraph office (telgrafhane) and the Mabeyn Kiosk were realized. The buildings next to the imperial pantry (kiler-i hümâyun), the office/residence of Eunuchs (harem ăgaları dairesi), and the telegraph office were designated for renovation after Mabeyn Kiosk. The petition

14 Cumhurbaşkanlığı Devlet Arşivleri (BOA), Hazine-i Hassa Ebniye Anbarları (HH.EBA.) 679, 10 February 1325 (23 February 1910); 804/29/3, 15 April 1330 ( 28 April 1914).

15 Müjde Dila Gümüş, "II. Meşrutiyet’te Saray İçin Çalışmak: Vedad (Tek) Bey’in Sermimarlık Dönemi”, (PhD. dissertation, Istanbul University, 2018), 199-263. All 85 preliminary estimate notebooks on Y1ldı Palace by Vedad Bey are examined in my dissertation, and only selected examples are included in this article.

16 Notebook numbered 200 and titled "Roof repair and some other repairs in Y1ldiz Palace." Presidency of The Republic of Turkey Directorate of State Archives (BOA), Hazine-i Hassa Ebniye Anbarları (HH.EBA.) 684/4, 23 October 1326 (5 Kasim 1910).

17 Notebook numbered 252 and titled "Repair of the Mabeyn Kiosk in Y1ldız Palace.” A petition written by Halid Ziya was attached to this notebook. Halid Ziya mentioned that it states that the sultan will spend the summer in Yildiz next year (1327/1911). Therefore, the repair of Mabeyn Kiosk should be started as soon as possible. Presidency of The Republic of Turkey Directorate of State Archives (BOA), Hazine-i Hassa Ebniye Anbarları (HH.EBA.) 688/4/2, 22 January 1326 (4 February 1911). 
written by Halid Ziya Bey on 8 March 1911 states the Sultan's desire to have the said work done rapidly. ${ }^{18}$ Vedad Bey's notebooks, all labelled in consecutive order, have similar contents concerning the repair of the walls, doors, shutters and frames, and the covering of some rooms and courtyards with floral ornamented tiles. ${ }^{19}$ The common emphasis in each of them is the fact that, as far as possible, the renovations should be done based on the original work.

When compared with others, Vedad Bey's notebooks concerning the Sultan's Pavillion (Daire-i Hümâyun), contain more detailed explanations and information. For instance, by way of a solution to the darkness on the lower corridor, Vedad Bey gave instructions for the removal of all the door spandrels on the corridor. Small dotted art nouveau glasses would be installed instead of the old spandrels, and yellow nails would be used to fix them. ${ }^{20} \mathrm{He}$ also instructed that the bath's cracks should be repaired "with intense care," 21 and the apartment's toilet was removed and replaced by a new stone one made of white and flawless Marmara marble, the same as in the Şale Mansion. ${ }^{22}$ The examples above show that when it comes to the Sultan's Pavillion (Daire-i Hümâyun), the architect emphasizes various details from the nails' color to the perfection of the marble to be used.

There were a few interventions in the palace gardens as well, such as the replacement of a drawbridge. Vedad Bey wanted to replace the said bridge located at the harem garden with a fixed bridge made of concrete but then he became concerned that its construction would take a long time and changed the construction material. ${ }^{23}$ Another example is of the construction of a new toilet in the garden, whose walls and the floor were covered with tiles. ${ }^{24}$ The entrance exterior façade of the Ada Kiosk was removed and renovated, and a coffee stove was added to the kiosk. ${ }^{25}$

Besides the renovations mentioned above, Vedad Bey designed wooden soldier sentry boxes to be placed in various parts of the palace, ${ }^{26}$ which reflect a micro-example of Vedat's revivalist style. Six different profiles were specified with the letters A, B, C, D, E, and F for the sentry boxes with a square plan with beveled edges, and covered with a cone with a polygonal base. The sentry boxes were placed in front of the Mecidiye Gate and at different locations within the palace garden. (F. 1, F. 2)

18 BOA, HH.EBA. 688/4/1, 23 February 1326 (8 March 1911).

19 Notebooks numbered 273, 274, 275, 276. BOA, HH.EBA. 704/25/58, 19 February 1326 (4 March 1911).

20 Notebok numbered 619. BOA, HH.EBA. 767/37, 24 December 1329 (6 January 1914).

21 Notebok numbered 613. BOA.HH.EBA.767-2-1, 22 December 1329 (4 January 1914).

22 Notebok numbered 617. BOA.HH.EBA.780-26-1, 24 December 1329 (4 January 1914).

23 Notebok numbered 536. BOA, HH.EBA. 738/13/1, 1 April 1329 (14 April 1913). Vedad Bey's petition dating 23 April 1329 (3 May 1913). BOA.HH.EBA.738-13-2.

24 Notebok numbered 540. BOA, HH.EBA. 734/16, 1 April 1329 (14 April 1913).

25 Notebok numbered 624. BOA, HH.EBA. 768, 29 December 1329 (11 January 1914).

26 Notebok numbered 429. BOA, HH.EBA. 711/25/2, 5 June 1328 (18 June 1912). 


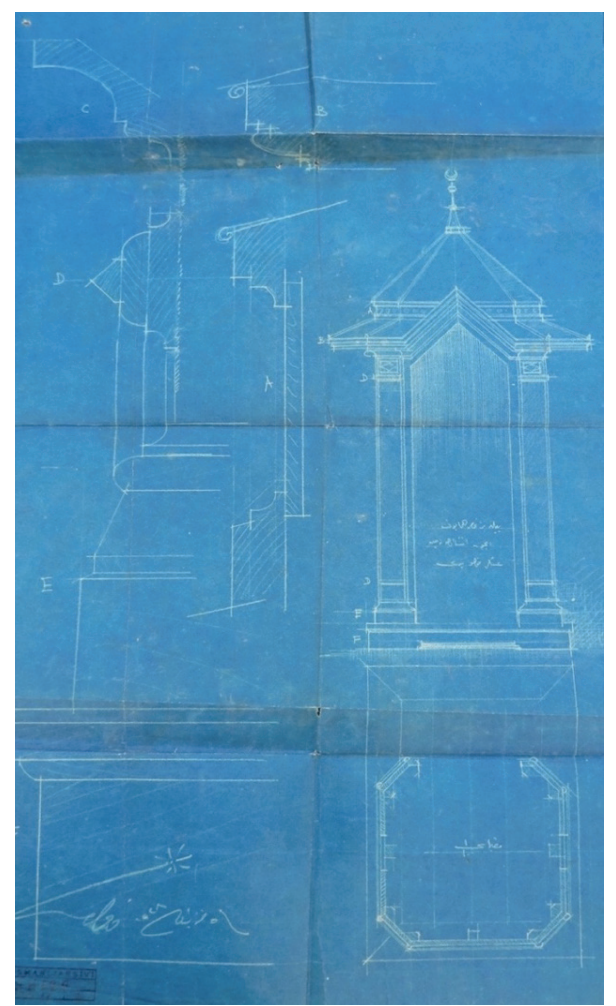

F. 1: Architectural projects of the soldier sentry boxes dated 5 June 1328 (18 June 1912) and signed by Vedad. (BOA.HH.EBA.711.25.2)

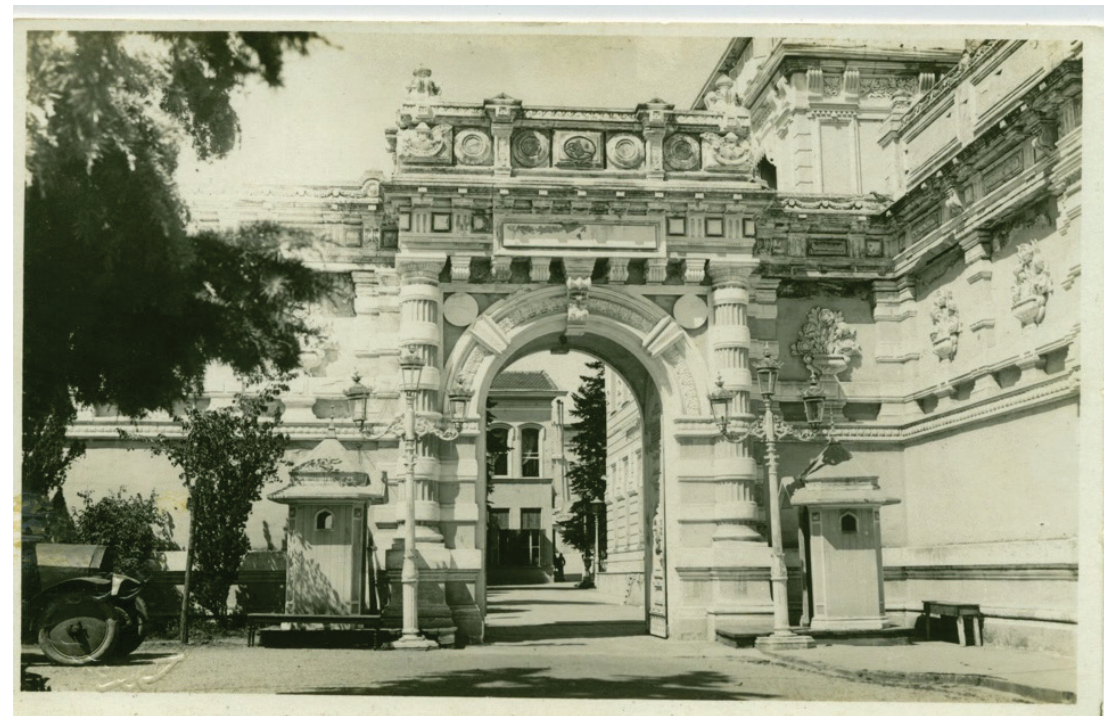

F. 2: A photograph of the harem gate dating 1924. Soldier sentry boxes designed by Vedad Bey can be seen on both sides of the gate. (İBB Atatürk Kitaplığı, Bel_Mtf_001273) 


\section{Destruction of Yıldız Palace Cuisine}

The most large-scale intervention at Y1ldı Palace under Vedad Bey's supervision was the destruction of the palace cuisine. In his petition on the destruction of the kitchen, Vedad Bey stated that since there was no need for the palace kitchen anymore, it would be demolished, and its land would turn into a garden. ${ }^{27}$ Abdülhamid II's court painter (ressam- $\iota$ hazret-i şehriyari) Fausto Zonaro also mentions in his memoir that the palace kitchen's destruction was due to its dysfunction: "Lots of servants and officers were displaced. All of the artists of the sultan's theater, the whole marching band, two hundred gardeners, two hundred cooks; the kitchen was destroyed because the food was not served anymore, neither to the Palace nor to the outside." ${ }^{28}$

Information about the former kitchen is limited to Fuat Ezgü's remark that there used to be a palace kitchen on the right hand side of the street opposite Hamidiye Mosque. ${ }^{29}$ The plan of the layout of Y1ldiz Palace was published in L'Illustration in 1909, shortly after Abdülhamid II's dethronement, providing some useful data to determine the location of the palace kitchen. According to the plan, the palace kitchen (cuisine) was shown as a separate building between the Mabeyn Kiosk and the telegraph office, just behind the Agalar Pavillion (F. 3, F. 4). In the layout plan prepared by Sedad Hakk1 Eldem in the late $1960 s,{ }^{30}$ the land in front of the Imperial Pantry (Kiler-i Hümâyun) appears as a garden. (F. 5) The difference between the two plans dated 1909 and 1960's suggests that the palace cuisine was located between the Imperial Pantry and the Telegraph Office before it was demolished.

27 BOA, HH.EBA.709/15/1, 2 August 1327 (15 August 1911).

28 Fausto Zonaro, Abdülhamid'in Hükümdarlı̆̆ında Yirmi Yıl (Fausto Zonaro 'nun Hatıraları ve Eserleri), trans. T. Alptekin, Lotto Romano (İstanbul: Yapı Kredi Yayınları, 2008), 292.

29 Fuad Ezgü, Yıldız Sarayı Tarihçesi (İstanbul: Harb Akademileri Komutanlığı, 1962), 40.

30 Sedad Hakkı Eldem, Boğaziçi Yalıları I (İstanbul: Devlet Güzel Sanatlar Akademisi Yayınları, 1969-1974), 43. 


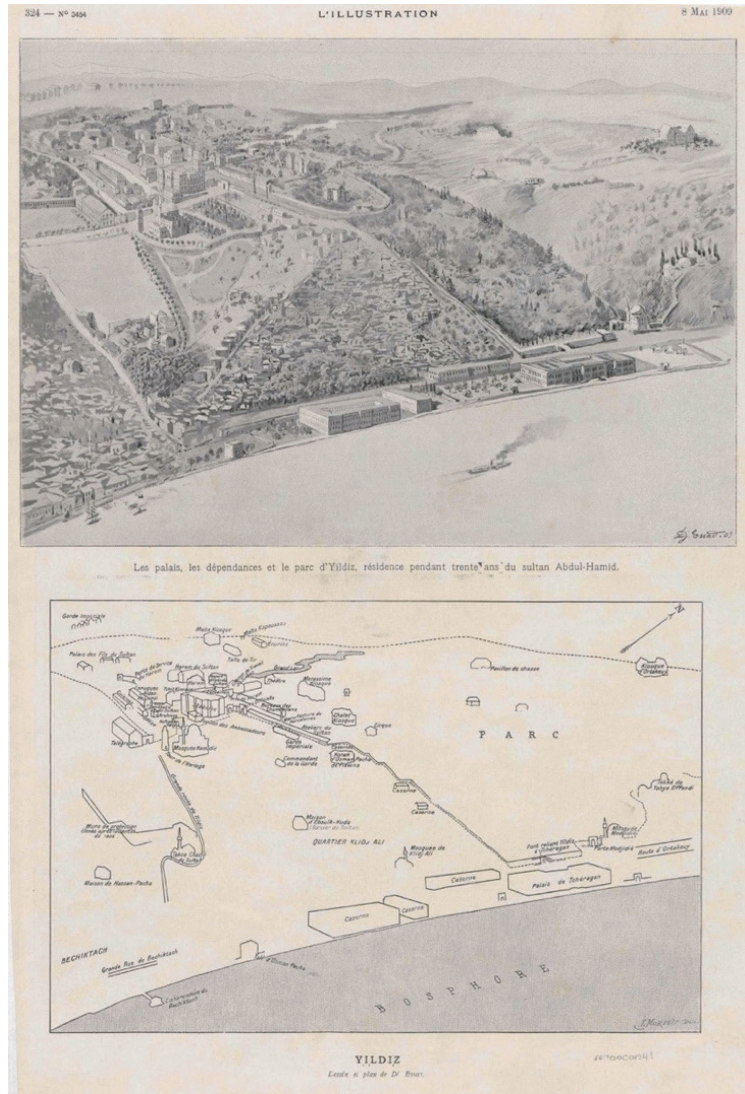

F. 3: Y1ld1z Palace Layout Plan published in L'Illustration on 8 May 1909. (SALT Research, Feridun Fazıl Tülbentçi Files)

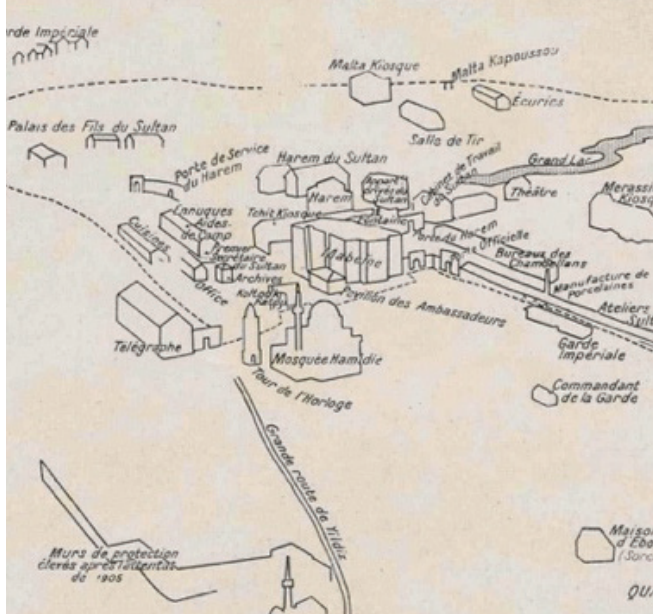

F. 4: Detail from the Y1ldiz Palace Layout Plan published in L'Illustration on 8 May 1909 (SALT Research, Feridun Fazıl Tülbentçi Files) 


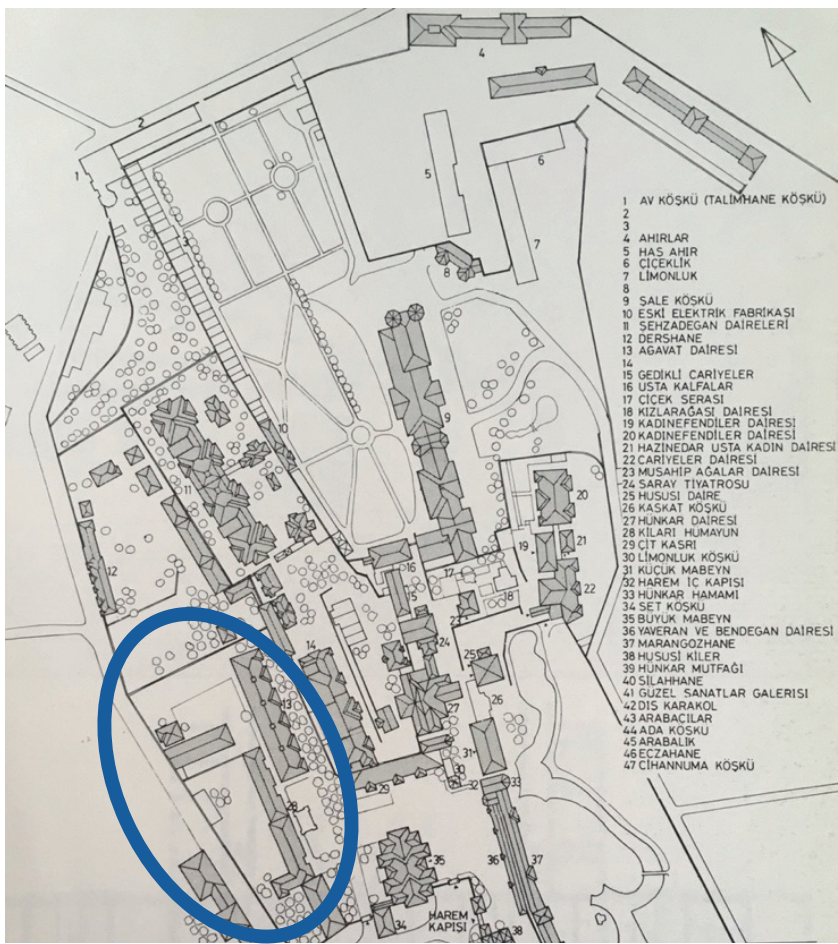

F. 5: Layout Plan of Yıldız Palace (Sedad Hakkı Eldem, Boğaziçi Yalıları I, 43.)

Vedad Bey prepared three projects concerning the new palace cuisine. The first is titled "Construction of the marble washbasins in the kitchen that will be installed in the forge (demirhane) in Imperial Yildız Palace."”11 The first project reveals that it was planned to re-organize the forge as a cuisine; additionally, it includes the design and production instructions for the marble washbasins to be used in the new kitchen (F. 6). About the production of washbasins, Vedad Bey gave the following instructions: 28 marble sinks will be produced from Marmara marble in coordination with the drawings, one hot and two cold taps will be installed, a cabinet will be placed under each sink, and a shelf will be placed opposite it, and the back of the shelves will be covered with zinc. The second project on the subject includes instructions for removing the stoves in the old kitchens from their places and transferring them to the forge. The final project contains instructions for connecting water to the kitchen. The following year, Vedad Bey gave various instructions such as installing a boiler with a water heater, producing a shelf, and relocating the taps to eliminate some deficiencies in the new kitchen. ${ }^{32}$ 


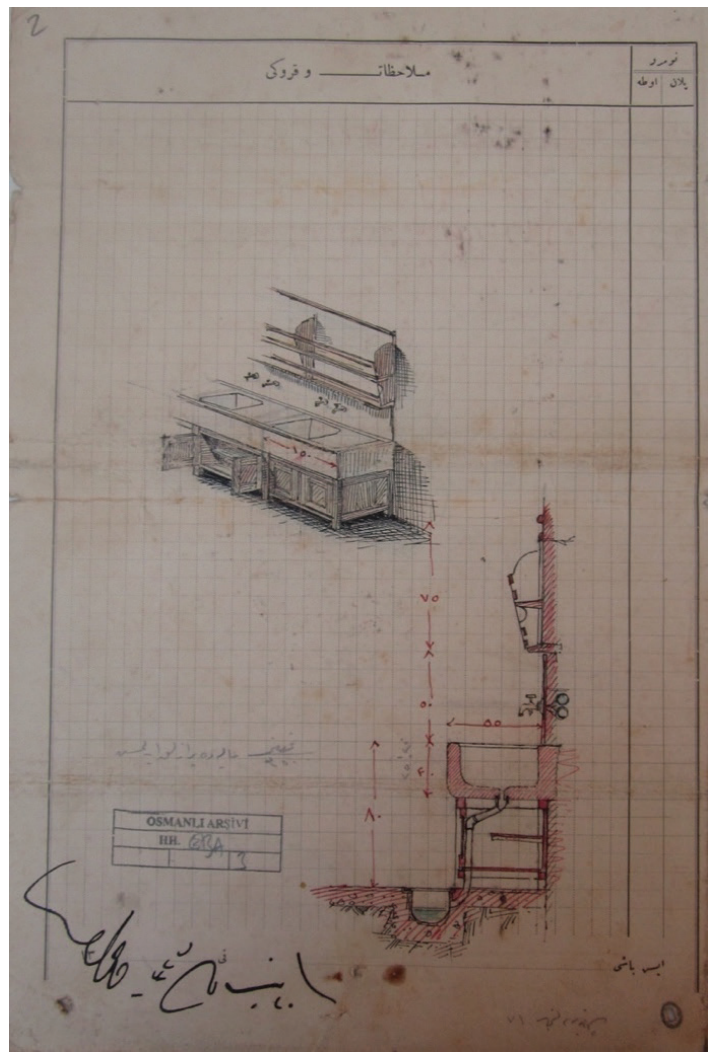

F. 6: Architectural drawings of the washbasins dating 20 February 1327 (4 March 1912), signed by Vedad. BOA,HH.EBA.711/6/3)

\section{Conclusion}

Yildiz Palace continued to be used as a residence of the Ottoman dynasty after Abdulhamid II's dethronement. Yildiz Palace was the second most renovated complex by the chief court architect Vedad Bey, reflecting the extent to which the complex was made more functional during the Second Constitutional Period. Mabeyn Kiosk, Şale Kiosk, Ceremony Kiosk (Merasim Köşkü), Small Mabeyn (Küçük Mabeyn), the museum (müzehâne), the New Kiosk (Yeni Köşk), Mabeyn Kiosk, Cihannüma Pavillion, Şale Kiosk and Çit Pavillion, the telegraph office (telgrafhane), the buildings next to the imperial pantry (kiler-i hümâyun), the office/residence of Eunuchs (harem ağaları dairesi) were repaired under Vedad Bey's supervision to make the palace a suitable residence for the sultan and his entourage. Vedad Bey's frequent emphasis that the repairs should be carried out according to the palace buildings' original features is noteworthy in exemplifying the period's understanding of restoration. In general, most of the repairs mentioned above were simple repairs that were carried out for practical 
reasons and cannot be documented today. The Sultan's Pavillion (Daire-i Hümâyun) was another building renovated by Vedad Bey. Comparing the detailed examinations in the notebooks concerning the Sultan's Pavillion to his notebooks on other buildings demonstrates that Vedad Bey paid particular attention to Sultan's Pavillion.

The construction of the soldier sentry boxes was a unique project among the other tasks that Vedad Bey undertook on the palace since designing them was an opportunity for him which was totally separate from the routine repairs mentioned above. The soldier sentry boxes, not recognized in other studies before this one, are examples that Vedad Bey also applied his revivalist approach on a micro-scale.

The most comprehensive intervention in the palace during the Second Constitutional Era was the demolition of the palace kitchens. A comparison of the layout plans of the palace from 1909 and the 1960s reflect that the old palace kitchens had been located between the imperial pantry and the telegraph office. The demolition process of the Y1ldiz Palace kitchens and Vedad Bey's architectural drawings regarding the new kitchen are other findings of this research; the architectural features of the old kitchen and the causes of its destruction are open to further and deeper research on Y1ldiz Palace.

Peer-review: Externally peer-reviewed.

Conflict of Interest: The author has no conflict of interest to declare.

Grant Support: The author declared that this study has received no financial support.

Hakem Değerlendirmesi: Dış bağımsız.

Çıkar Çatışması: Yazar çıkar çatışması bildirmemiştir.

Finansal Destek: Yazar bu çalışma için finansal destek almadığını beyan etmiştir.

\section{References/Kaynakça}

Ahmad, Feroz. The Young Turks; the Committee of Union and Progress in Turkish Politics, 19081914. Oxford: Clarendon Press, 1969.

Batur, Afife. "Yıldız Saray1." Dünden Bugüne İstanbul Ansiklopedisi. 7. İstanbul: Türkiye Ekonomik ve Toplumsal Tarih Vakfı Yayınları, 1993, 520-556.

Bilgin, Bülent. “Türk Saray Mimarisinin Gelişmesi Çerçevesinde Yıldız Sarayı.” PhD. Dissertation, Istanbul University, 1993.

Deringil, Selim. The Well-protected Domains: Ideology and the Legitimation of Power in the Ottoman Empire, 1876-1909. New York: I.B. Tauris Press, 1998.

Ezgü, Fuad. Yıldız Sarayı Tarihçesi. İstanbul: Harb Akademileri Komutanlığı, 1962.

Georgeon, François. Sultan Abdülhamid. Translated by Ali Berktay. İstanbul: İletişim Yayınları, 2015.

Gümüş, Müjde Dila. “II. Meşrutiyet’te Saray İçin Çalışmak: Vedad (Tek) Bey'in Sermimarlık Dönemi.” PhD. Dissertation, Istanbul University, 2018. 
Eldem, Sedad Hakkı. Boğaziçi Yalıları I. İstanbul: Devlet Güzel Sanatlar Akademisi Yayınları, 1969-1974.

L'Illustration, 8 May 1909, Issue 3454, 324.

M. Vedad Tek: Kimliğinin İzinde Bir Mimar. Edited by Afife Batur. İstanbul: Yapı Kredi Yayınları, 2003.

Mahmud Şevket Paşa'nın Sadaret Günlü̆̈̈̈. Prepared by Murat Bardakçı. İstanbul: İş Bankası Kültür Yayınları, 2014.

Özkan, Süha. “Mimar Vedat Tek (1873-1942)”. Mimarlık 11-12 (1973): 45-51.

Saz, Leyla. 19. Yüzyılda Saray Haremi. İstanbul: Cumhuriyet Kitapları, 2000.

Simavi, Lütfi. Son Osmanlı Sarayında Gördüklerim. İstanbul: Örgün Yayınları, 2004.

Tek, Nihad. “N. Sahir S1lan'a Mektup”. M. Vedad Tek: Kimliğinin İzinde Bir Mimar. Edited by Afife Batur. İstanbul: Yapı Kredi Yayınları, 2003, 385-394.

Tuğlacı, Pars. Osmanlı Mimarlı̆̆ında Batılılaşma Dönemi ve Balyan Ailesi. İstanbul: İnkılap ve Aka Kitabevleri, 1981.

Türker, Deniz. "Ottoman Victoriana: Nineteenth-Century Sultans and the Making of a Palace 17951909.” PhD. dissertation, Harvard University, 2016.

Uşaklıgil, Halid Ziya. Saray ve Ötesi. İstanbul: Özgür Yayınları, 2003.

Yolcu, Cengiz. "Bulgar Çarı 'Çarlar Kenti’nde.” Osmanlı İstanbulu III. Edited by Feridun M. Emecen, Ali Akyıldız and Emrah Safa Gürkan. İstanbul: 29 Mayıs Üniversitesi Yayınları, 2015.

Zonaro, Fausto. Abdülhamid'in Hükümdarlığında Yirmi Yıl (Fausto Zonaro'nun Hatıraları ve Eserleri). Translated by T. Alptekin and Lotto Romano (İstanbul: Yap1 Kredi Yayınlar1, 2008).

\section{Archival Documents}

Presidency of The Republic of Turkey Directorate of State Archives (BOA). Hazine-i Hassa Ebniye Anbarlar1 (HH.EBA).666-25-5, 669-67-2, 679, 804-29-3, 688.4.2, 732.39.6, 684-4, 688.4.2, 6884-1, 704-25-58, 767-37, 738-13-1, 734-16, 768, 711.25.2, 709.15.1, 709.15.1, 704-25-61, 689-56, 705-19, 767-2-1, 780-26-1, 738-13-2. 